Article

\title{
Building the Green Infrastructure of Belgrade: The Importance of Community Greening
}

\author{
Ivan Simić *, Aleksandra Stupar and Vladan Djokić \\ Department of Urban Planning, Faculty of Architecture, University of Belgrade, Bulevar kralja Aleksandra 73/2, \\ 11000 Belgrade, Serbia; stupar@afrodita.rcub.bg.ac.rs (A.S.); vdjokic@arh.bg.ac.rs (V.D.) \\ * Correspondence: ivan.simic@arh.bg.ac.rs; Tel.: +381-638-648-188
}

Received: 21 February 2017; Accepted: 16 June 2017; Published: 5 July 2017

\begin{abstract}
Due to its important role in increasing human well-being and providing space for ecosystem services, green infrastructure has gradually become an integral part of urban development strategies. Focusing on the activities of community greening, the article considers this approach toward the application of urban green infrastructure as a part of a broader strategy related to the resilience of cities. The neighborhood/district level will be emphasized and the analysis will be conducted in two areas of the Serbian capital Belgrade-Block 45 in New Belgrade and the Savamala neighborhood in the historical city core. Representing two different epochs of Belgrade's development, they are characterized by different typologies, while the characteristics of community greening also differ in several aspects, including purpose, model of organization, and involved stakeholders/participants. The green space of the identified typical morphological units has been cultivated and maintained in two different ways-institutional (provided by the public company) and non-institutional (community greening) - and their impact on the quality of the local GI will be compared. The analysis intends to provide data on the level of biodiversity, multi-functionality, and maintenance of green spaces which will show the effect of both applied approaches. Particular attention will be given to the tensions and challenges of the local context: the adoption of plans and regulations that are in accordance with contemporary trends, as well as the drawbacks in their implementation. Furthermore, the possibilities of community greening will be elaborated, as future steps for achieving the formal green infrastructure (hereinafter GI) standards at the neighborhood/district scale.
\end{abstract}

Keywords: green infrastructure; community greening; urban planning and design; resilience; sustainability; Belgrade; local community

\section{Introduction}

The new discourses of ecology have influenced a shift of planning paradigms, incorporating new knowledge and imperatives [1-3]. Consequently, the ecosystem approach to planning emphasizes the importance of human well-being in the context of an integrated socio-ecological system. This approach is based on several principles-multi-scalability, hierarchical structure of ecosystems, a relationship between elements and processes, connectivity, and spatial continuity [4] — while its built and social elements can be considered as the specific types of physical and biological components $[4,5]$.

Being a part of this discourse, the term green infrastructure appears in recent studies as an important element of new planning/design strategies targeting sustainable development and resilience [6-8], as well as climate change adaptation [9]. Supporting a set of ecological and cultural functions $[5,10]$, it also represents a contribution to the general well-being of people [11-13]. Benedict and McMahon [6] define GI as an interconnected network of green spaces which conserves values and functions of a natural ecosystem, providing associated benefits for human population. Considering GI as an ecological framework needed for environmental, social, and economic sustainability, they 
claim that this planning approach to open spaces differs from conventional ones because it integrates conservation values and anticipated actions with land development, growth management and the building of infrastructure.

Green infrastructure provides environmental services in urban areas, which is a prerequisite for ensuring biodiversity, social, and territorial cohesion, sustainable development, and overall human well-being $[12,13]$. By implementing GI, it is possible to achieve a high level of accessibility, connectivity and attractiveness of its elements in predominantly residential, working or recreational areas. Consequently, the necessary multi-scale approach, targeting metropolitan (regional/city) level, districts/neighbourhoods, and individual sites [5], involves the assessment and planning of spatial configurations composed of landscape patterns and ecological processes. Simultaneously, the analysis of their interaction indicates key points for physical linkages-both existing and possible ones [14].

The significance of green infrastructure has become recognized and gradually introduced by numerous cities as formal (top-down) and informal (bottom-up) initiatives. For example, Berlin and Malmö have crafted a special regulation and standardization of the network of green and open spaces, using the top-down planning approach $[15,16]$. The experiences of Berlin and Malmö were adopted by Seattle, which established an innovative standard of regulation and preservation of biotopes (2006, extended in 2009). Developing a system of evaluation and standardization called the Seattle Green Factor (SGF), the city emphasized the importance of promoting attractive and environmentally friendly functional areas, as well as its elements (e.g., green roofs and walls, permeable paving, cultivation of food, etc.) [17].

At the same time, there is a growing volume of research focused on the bottom-up strategies of greening, initiated and implemented by local stakeholders. For example, Krasny and Tidball [18] define a framework of 'civic ecology', based on activities labelled as urban community greening. This term refers both to a diverse set of management/supervising environmental practices conducted by a community and to their role in a larger social-ecological system. Lovell and Taylor [13] examine community greening as a multifunctional element of GI, emphasizing its ecological importance for the resilience of socio-ecological systems perceived via innovation, adaptive management and social learning. The issue of community greening has been also studied in the context of Swedish cities by Colding and Barthel [19]. They described it as 'urban green commons', important for urban resilience based on ecological and social diversity. Furthermore, the specificities of informal green spaces, especially their uncertain legal, socio-economic and ecological status, were tackled in recent studies [20].

In general, community green areas can be a result of different individual or collective actions located on private, common or public area. Their spatial configuration and relation to the built and natural surrounding could also vary, influencing the components which constitute GI. However, all forms of community greening are physically linked to the level of the neighbourhood/district or the individual plot/building. Since their elements contribute economically and ecologically to human well-being, inducing changes at higher spatial and management levels, they are eligible to become a part of the formal, strategically-planned network of GI [11,21]. Simultaneously, the involvement of public participation provides new opportunities for the empowerment of the local community. Community greening is also vital for the creation of urban spaces with polyvalent and multifunctional qualities [13], while small-scale greening projects could induce broader transformation of city's GI, which might be more extensive and economical than the one achieved via the conventional top-down planning [11].

The implementation and upgrading of GI in Serbia has its own specificities which are the result of a comprehensive transitional process of an ex-socialist society shaken by the decade-long Balkan war conflicts, international sanctions, NATO bombing, and anti-governmental protests. Furthermore, the strict hierarchy of the Serbian planning system additionally complicates implementation of lower-ranged plans and documents. For example, the Master Plan of Belgrade 2021 [22] subordinates all other plans and regulations at lower spatial levels. Along with this legally-binding document, 
urban development is guided by the Strategic Development Plan of the City of Belgrade [23] and local environmental development plans (LEAP, Belgrade, Serbia), which recognize the importance of local community initiatives (including the greening activities), but do not have a legally-binding character [24]. Therefore, the possibility of implementation is significantly reduced due to the lack of adequate official mechanisms for inclusion of local greening. Furthermore, there are other problems underlined by the LEAP of the municipality Savski Venac (although applicable in the whole metropolitan area of Belgrade)—non-systematic and inconsistent management of green spaces; poorly maintained and degraded green areas; and functionally and visually unattractive green spaces [24].

An important step towards the successful implementation of plans represented the study Green Regulation of Belgrade [25], initiated in 2002 and conducted by the University of Belgrade-Faculty of Forestry and the Urban Planning Institute of Belgrade. It provided a comprehensive insight into green areas of Belgrade (GIS of biotopes), introduced contemporary principles of GI and enabled identification of so-called morphological units, according to the patch-corridor-matrix model of landscape structure [26-29]. Furthermore, the elements of the study were used in the Master Plan of Belgrade 2021 in which "the green core of Belgrade" was distinguished as a unique and comprehensive area of green and blue corridors, including the river courses of the Danube and the Sava [22]. The Plan indicates the components of GI on the metropolitan level—mainly river islands, coastal parks, forelands, lakes, ponds, and marshes, setting up a conceptual foundation for planning at the metropolitan/city scale. However, the strategies and plans on the local level do not recognize sufficiently the principles of the GI approach, although its importance could be identified in action plans, within the context of climate change adaptation and mitigation. For example, in early 2015, the city of Belgrade adopted the Action Plan for Climate Change Adaptation (hereinafter APCCA), emphasizing the planning and implementation of GI networks throughout the metropolitan territory as a measure of the highest priority [30]. Based on the concept defined by the Green Regulation of Belgrade, this action plan gradually introduces the preferred ecosystem approach to the level of metropolitan and municipality planning [25].

Considering all the benefits of community greening, as well as the local specificities of the Serbian socio-economic context, the article will focus on the case of Belgrade and two selected urban areas-Block 45 (municipality of Novi Beograd) and Savamala (occupying parts of municipalities-Stari Grad and Savski Venac). Representing two different epochs of Belgrade's development, they are characterized by different typology, while the characteristics of community greening also differ in several aspects including purpose, model of organization and involved stakeholders/participants. The impact of community greening on the quality of local GI will be identified by comparing the green areas exposed to two different types of cultivation and maintenance-non-institutional (community greening) and institutional (provided by the public company). The analysis should provide data which will show the difference created by both approaches, especially related to the level of biodiversity, multi-functionality and maintenance of green spaces at the local scale. Furthermore, the possibilities of community greening will be elaborated, as future steps for achieving the formal GI standards at the neighborhood/district scale.

\section{Case Studies}

\subsection{Methods}

The analysis of the selected study areas was conducted at the level of the urban matrix, defined according to the 'patch-corridor-matrix model' [27]. It represents a dominant type of urban land cover in the terms of area, connectivity degree, continuity, and control over landscape [27,31]. Morphological units, as basic matrix elements composed of buildings with their immediate surrounding areas, are identified according to the Belgrade's GIS (MapSoft, Belgrade, Serbia) of biotopes [26,29], and used for the analyses of the selected areas/matrices and the impact of two applied regimes of greening and maintenance. The evaluation of selected units is based on several criteria defined in the Green 
Regulation of Belgrade: the ratio of pervious surfaces, share of evapotranspirational surfaces, areas under treetops, vegetation structure of biotopes, multi-functionality, visual quality [32], as well as the condition of cultivation and maintenance. These criteria also match the parameters used in the GI methodologies applied in Berlin, Malmö, and Seattle [15-17]. The indicators used for calculating the ratio/percentage of pervious surfaces, evapotranspirational surfaces and the areas under treetops are quantitative and the data are available in the Belgrade's GIS of biotopes. However, in order to achieve a higher accuracy, the high-resolution aerial images of the selected areas were also used, as well as the photos taken on-site. The data related to multi-functionality were gathered by regular monthly observations and photographing, indicating the change of the number and type of activities. The information describing the visual quality, as a subjective aesthetic category, represent the result of the descriptive qualitative assessment based on the interviews conducted in the study areas. All selected criteria provide a sufficient set for the evaluation of the condition and quality of GI before and after community greening. Since the selected data are also easily measurable, the methods used in this research are highly applicable.

\subsection{Study Areas}

The selected areas of Belgrade represent two different planning approaches—Block 45 in New Belgrade was designed in accordance with the imperatives of the 20th century Functionalist city, while Savamala reflects elements of the European urbanism of the 19th century (Figure 1). Consequently, their morphological, ecological, and sociological characteristics are drastically opposed. Plans and regulations of the city of Belgrade also recognize differences between these two areas, both on the level of built and green areas (Table 1). According to urban-morphological parameters, the Belgrade Master Plan 2021 [22] identifies their urban blocks as (1) open/Modernist (dominant in New Belgrade) and (2) perimeter (dominant in the traditional city core, including Savamala). However, both selected areas are situated in the same natural environment, so-called "Green core" of the city-along the river Sava, as a dominant component of the urban ecosystem. Due to equal natural conditions, their different structures could be compared in order to determine their uniqueness and trace the development of GI at the local level.

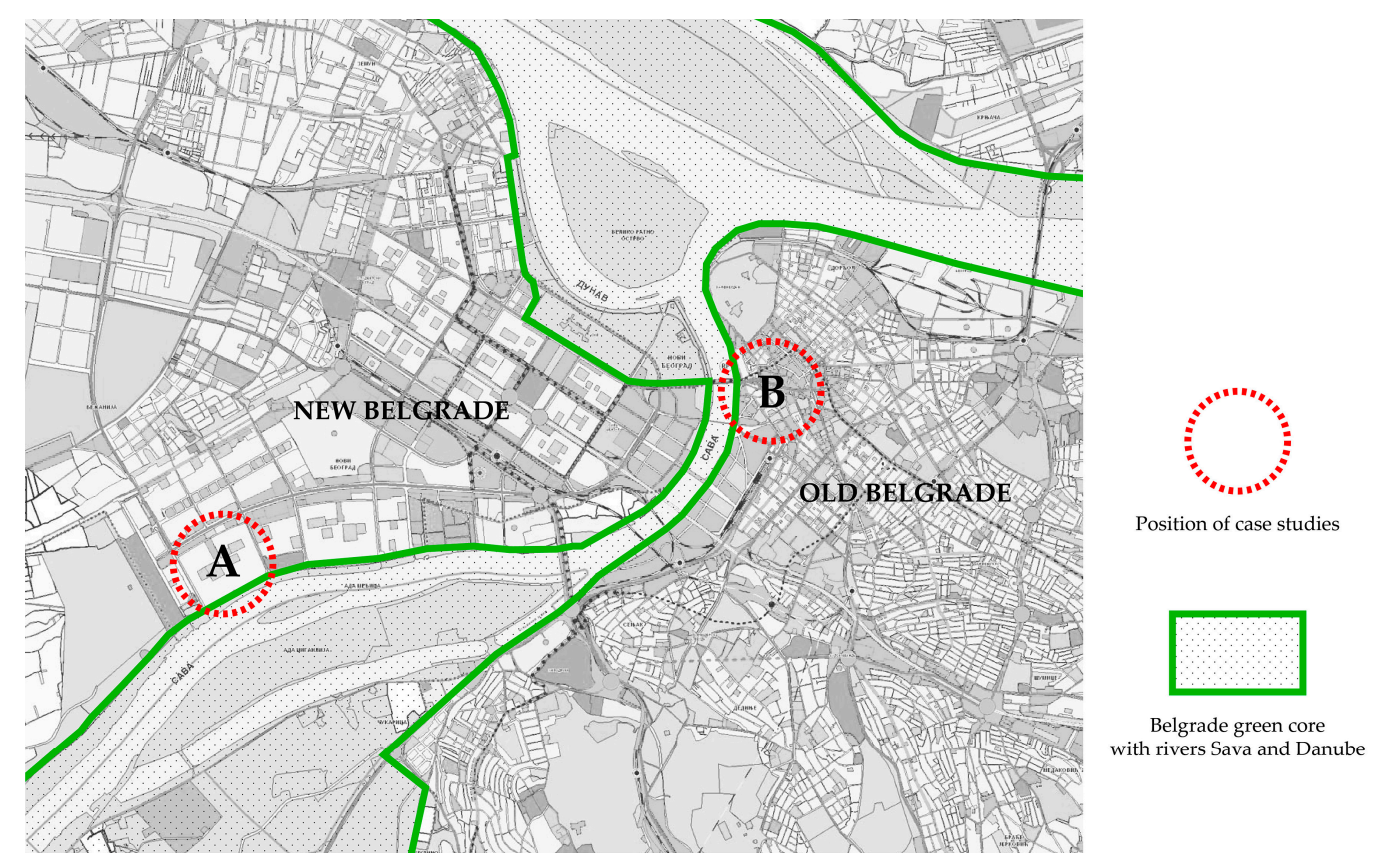

Figure 1. The position of Block 45 (A) and Savamala district (B) in relation to the Belgrade green core and the river Sava. Source: Master plan of Belgrade 2021. 
Table 1. The comparative review of basic urbo-morphological parameters of Block 45 (New Belgrade) and Savamala district (historical urban core).

\begin{tabular}{ccccc}
\hline & Floor Space Index & Population Density & Building Coverage (\%) & Green Area (\%) \\
\hline Block 45 & $1.2-2.2$ & $300-600 /$ ha & 30 & 30 \\
Savamala & $3.5-4.5$ & $400-800 /$ ha & 75 & 10 \\
\hline
\end{tabular}

\subsubsection{Block 45}

Block 45 is located in the municipality of New Belgrade, which has the largest surface of intra-block green spaces among all Belgrade municipalities (396.6 hectares). The block of 32,000 inhabitants occupies a strip of land on the left bank of the Sava River and it was implemented in 1966 as a unique urban entity for the extended local community. Green areas were initially planned as a park and a recreational area complementing the built structures. Consistent with the principles of Le Corbusier embedded in the Functionalist design of New Belgrade, buildings were supposed to be 'immersed in greenery' [33], providing a higher environmental quality. According to the Draft of the detailed regulation plan for blocks 45 and 70, the design of green spaces followed the standard of $22 \mathrm{~m}^{2} /$ inhabitant [34], but their quality and differentiation after implementation remained at low levels [35].

Responding to the unfavourable condition of some green spaces, their revitalisation and differentiation have been included in new plans, along with the elements of the preferred GI network. For example, the Draft of the detailed regulation plan for blocks 45 and 70 specifies new values which include, inter alia, "the preservation and improvement of the achieved high standards of living and understanding of emerging residents' needs" [34]. In terms of the GI development, the Action Plan for Climate Change Adaptation (APCCA) provides the foundation for the development of a network of green corridors along the promenade Lazaro Kardenas, which connects residents with the river Sava [30]. The green network is supposed to provide air-cooling by evapotranspiration, primarily via the avenue and small groups of trees. Setting permeable paving to reduce the outflow of atmospheric water, and constructing the canals and retention ponds along the dikes and banks should prevent floods. APCCA recommends use of local plant species, preservation, and improvement of urban forestation, promotion of ecological parks, and urban gardening, while recommending the introduction of green roofs and walls. All of these measures should increase the natural, cultural, and aesthetic values of targeted spaces, underlining their multiple role in creating a positive effect on mental and physical health and stimulating social interaction [30]. The plan also refers to administrative bodies and public companies as responsible for the implementation.

Based on the patch-corridor-matrix model and the Belgrade's GIS of biotopes, the elements of urban matrix were identified (Figure 2a). The northern part of the block (Figure 2b) consists of free-standing skyscrapers, whereas the southern part (Figure 2c) consists of U-shaped residential buildings with a smaller number of floors. The shape of the built structures also caused a different configuration of greenery. The morphological units in the northern part include a narrow strip of greenery around the buildings and small residual areas around playgrounds and parking lots. All of them have been maintained by the public company-Belgrade's City Greenery. The units of the southern part incorporate greenery within U-shaped buildings and the ground floor apartments have a narrow strip of secluded, quasi-private green space, while the remaining area, mainly covered with trees and shrubs, has a public character. The units of this part of Block 45 have been treated by two different greening approaches (community greening vs. institutional) and, therefore, represent the polygon of our analysis (options A and B-Figures 3A and 3B). Although identical in size and percentage of built area, the option $\mathrm{A}$ incorporates green space voluntarily maintained by residents, mostly owners of ground floor apartments, with a direct and easy access (Figure 3A). Their high interest in individual greening is mainly expressed through the cultivation of small trees, flowers, and low vegetation, while their activities contribute to the bio-diversity and stronger feeling of privacy within a common green space. Although under the official jurisdiction of the city, the community 
greening has spontaneously started two decades ago, as a reaction to poor maintenance, as well as a form of hobby and leisure [36]. According to self-organized residents, there seems to be a tacit agreement with relevant city institutions/agencies of local inhabitants taking control over landscaping. Meanwhile, the other morphological option (B) contains a public green space around buildings solely maintained by the public company—Belgrade's City Greenery (Figure 3B).
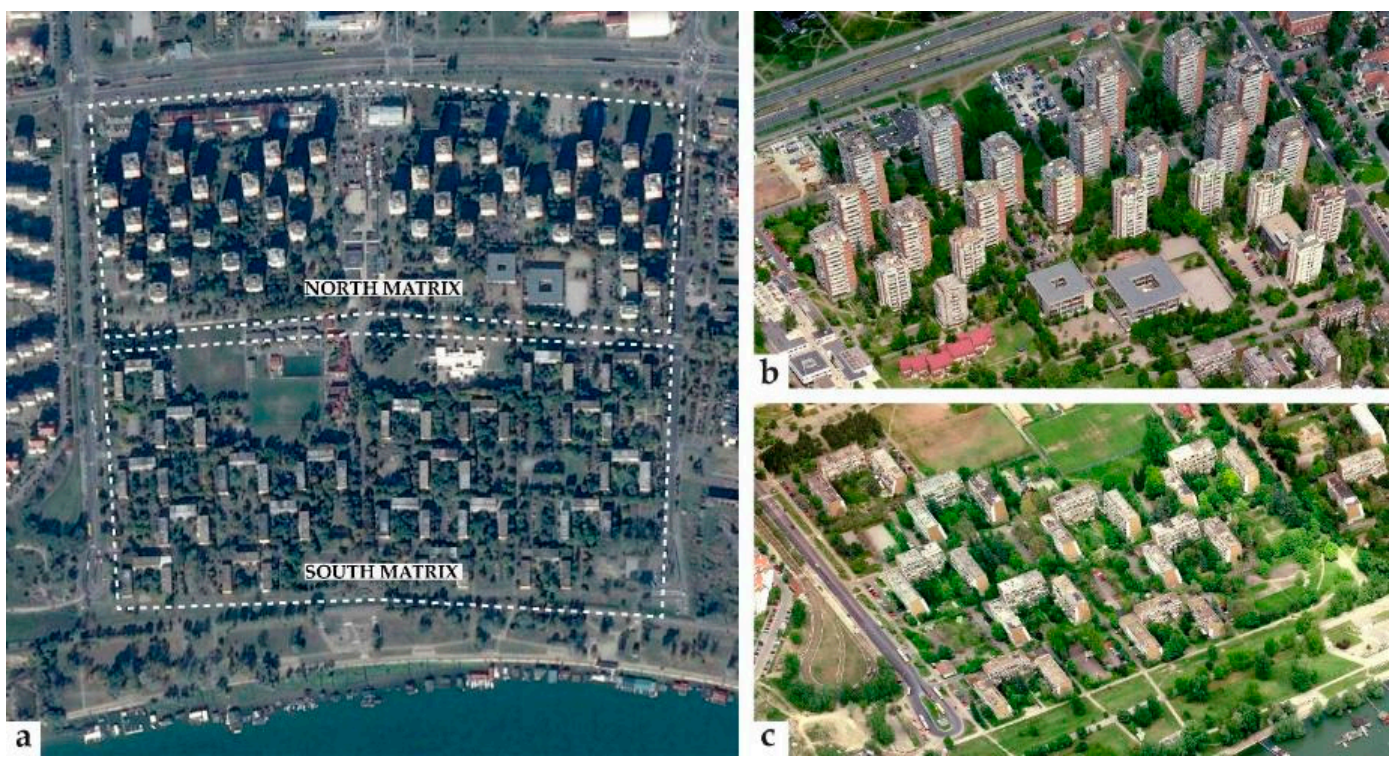

Figure 2. Aerial view of Block 45 (a), north (b), and south (c) part of urban matrix. Source: Google maps/Bing maps.
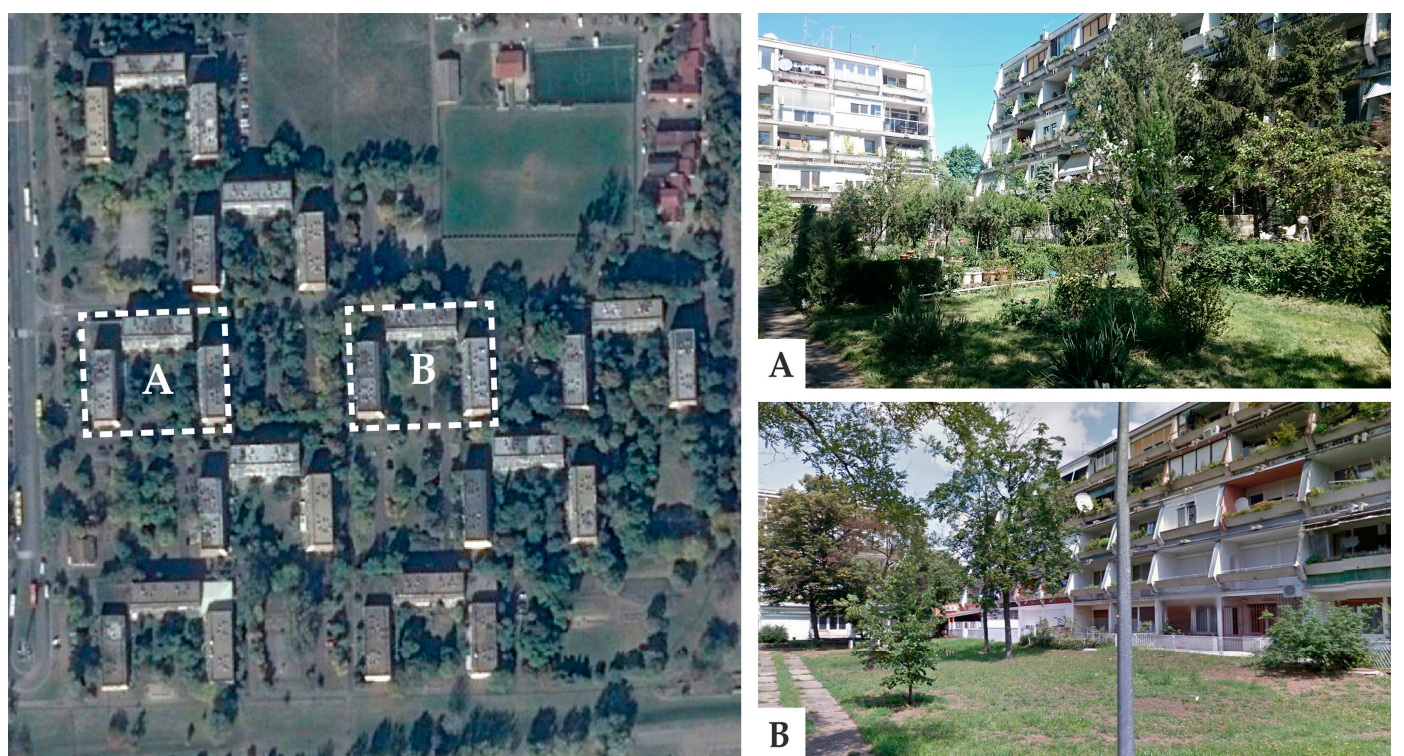

Figure 3. The aerial view of the south urban matrix. Source: Google maps; morphological units (A) and (B). Source: Authors own data.

\subsubsection{Savamala}

Savamala is located on a slope along the left bank of the river Sava, bounded on west by the street Gavrila Principa and the natural border of the Sava. The plans classify Savamala as a continuously-built urban fabric composed of perimeter urban blocks [22]. Along Karadjordjeva street, the urban tissue is 
homogeneous, composed of five- to seven-storey buildings. Urban fabric is discontinued along the riverbank, consisting of low-rise urban blocks with services and storage facilities.

The course of development of this centrally-located area was set in the mid-19th century by Prince Miloš Obrenović who ordered relocation of trading activities to the new Abadžijski bazaar in Savamala. The establishment of a new commercial zone triggered the progress of this downtown area which had an intensive interaction with the river docks during its prosperous times. However, this connection, as well as the construction of representative buildings in Karadjordjeva Street was interrupted in the early 20th century after the construction of the railway and the railway station. Savamala lost its significance and Karadjordjeva Street became a high-frequency transit zone. The flux of people and greenery between the Sava River and Karadjordjeva Street was interrupted, leading to the gradual degradation of urban and environmental quality.

Although ideas for the relief of road traffic and railway relocation have existed since the Master Plan of 1972, they have not been materialized. However, the construction of the new "Prokop" station represents an important step in improving the current condition, removing railway tracks and re-establishing a vital relationship between Savamala and the riverbank. Simultaneously, the interest in this part of the city has increased, since its degraded state is now perceived as a challenge for reactivation, especially in the civil sector, cultural, and artistic circles.

The green areas of Savamala have had a partial planning treatment. Although recognized as an urban district, it officially belongs to two municipalities. The area under jurisdiction of the municipality Savski Venac is covered by the aforementioned Local Environmental Action Plan (LEAP) which suggests the initiation of new plans and projects for this area, as well as repurposing of the Sava amphitheatre and launching of the current relocation plan of the railway station [24]. The action plan also follows the planning concept of green areas formulated in the Green Regulation of Belgrade and the Biotope Map of Belgrade [25,37], defining basic aims, including the use of GIS and the introduction of modern forms of green areas-e.g., pocket parks, roofs, and vertical greenery, etc., [24]. The document also emphasizes the role of open cooperation with citizens, private and non-governmental organizations, and the importance of public participation. Stimulating the preparation of various events (forums, exhibitions) and advertising material, LEAP supports the raising of environmental awareness. However, similar to the previous case of Block 45, the plan does not provide possible models of participation, governance, and funding of these 'green' projects.

Considering the elements of this matrix, in which streets act as corridors, the current situation indicates an almost entirely unused potential, especially related to non-existing tree lines. The main street corridor is Karadjordjeva Street, with a higher urban significance and its connection to the riverbank, is achieved by a network of smaller streets. However, the railroad blocks the direct contact between street corridors and the riverbank. The urban matrix is characterized by a densely-built structure of perimeter blocks, covered by a high percentage of asphalt, concrete, and other impervious surfaces (Figure 4). This condition implies fragmentation and low diversity of biotopes. The bits of nature are limited mainly to the small public green spaces between blocks. Consequently, the community greening of Savamala differs from Block 45.

The combination of high density and mixed-use led to different models of community organization, focusing greening activities mainly toward implementation of pocket parks, conducted by local organizations. For example, in 2013 Mikser festival organized the "Blue-green dream" workshop, bringing together local community and professionals in an effort to initiate greening of public spaces, planting rows of trees and placing urban furniture for horticulture [38] (Figure 5a,b). A public workshop on urban gardening "Zdravamala" - eng. Healthy-(Sava)mala, was held in 2015 in the space of the Spanish house (Figure 5c), the abandoned and severely damaged building currently used as an informal public space [39]. During the same year, the workshop entitled "Moje parče Savamale"—eng. My Piece of Savamala (Figures $4 \mathrm{a}, \mathrm{b}$ and $5 \mathrm{~d}$,e) brought together various stakeholders, focusing on the redesign of the pocket park in front of Mikser House [40]. This event represented a key point of transformation which is analysed and assessed in the next section. 

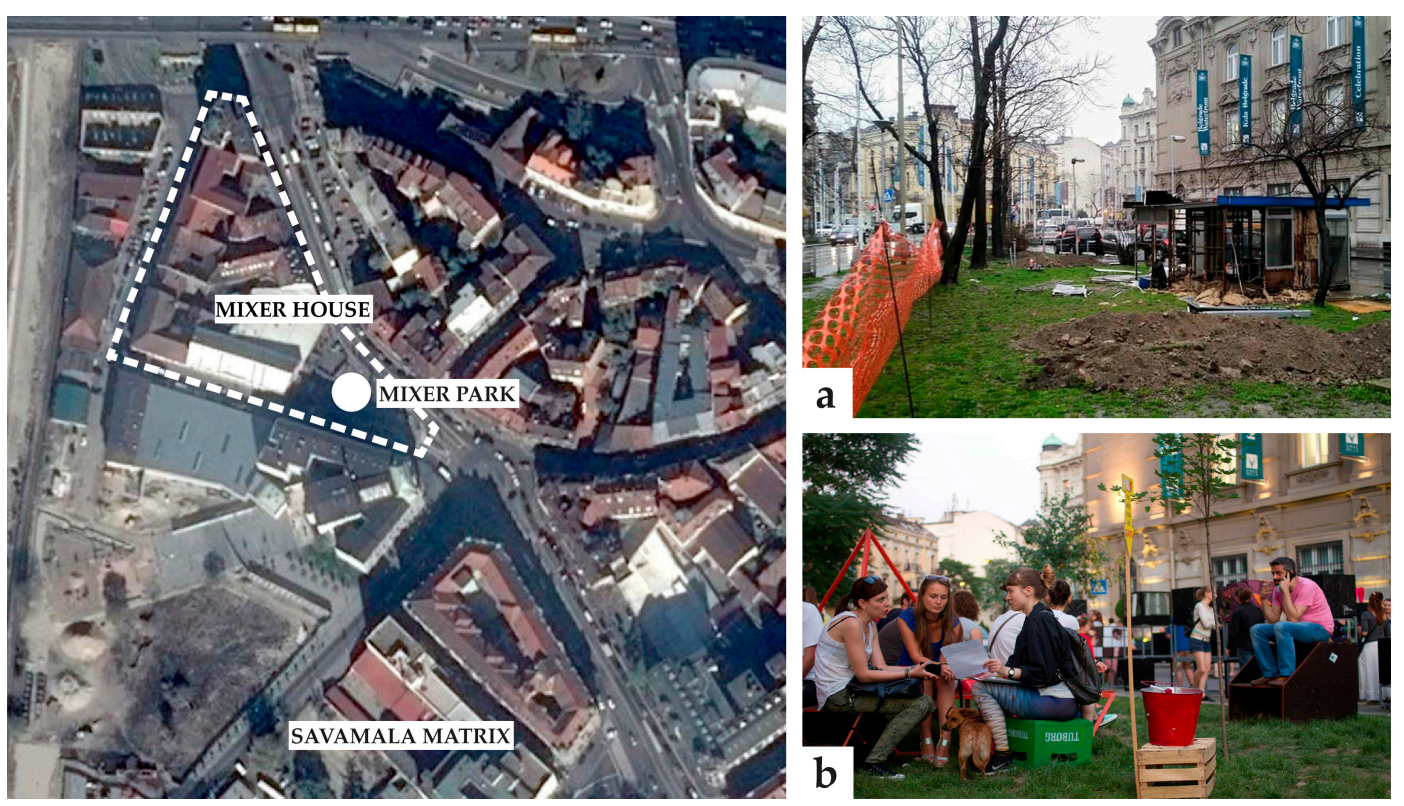

Figure 4. The aerial view of the Savamala urban matrix. Source: Google maps. The selected morphological unit before (a) and after (b) the workshop "Moje parče Savamale" and the removal of the gas station. Source: School of urban practices.
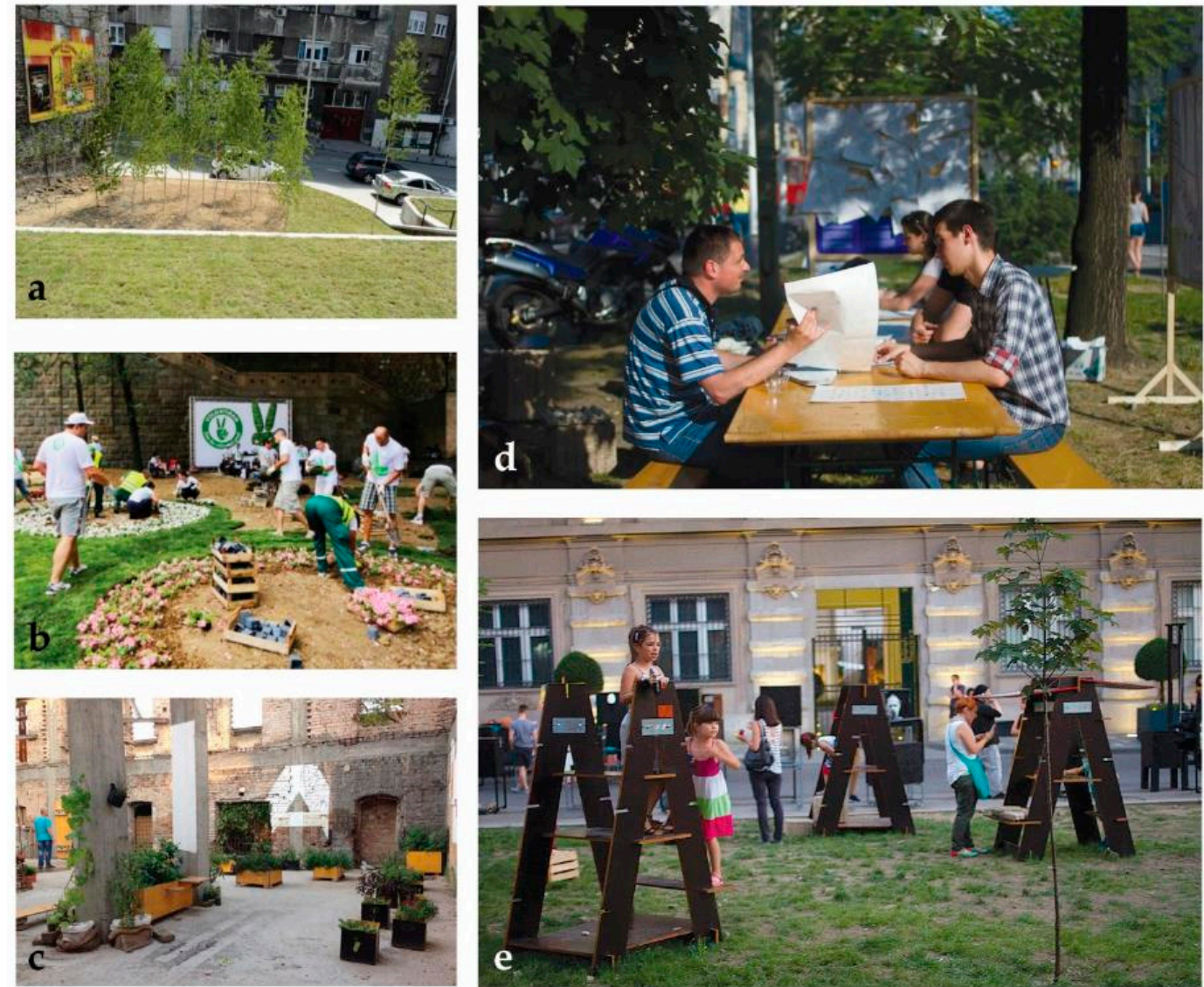

Figure 5. Savamala—community greening actions: "Blue-green dream" (a,b), "Zdravamala" (c) Source: Mixer organization; "My piece of Savamala" (d,e) Source: School of urban practices. 


\section{Results}

The case of Block 45 and its southern part exposed to both greening approaches shows that, on the level of morphological units, both options (A and B) have the same proportion of impervious surfaces composed of the flat roofs of three residential buildings (U-shape) and the access paths to building entrances and green area. In both options, the interventions which would give them higher levels of permeability (e.g., installation of green roofs) have not been made. According to the indicators of ecosystems' quality, the gardening activities in the morphological option A have a higher intensity and diversity than the usual set of activities conducted by the public greening company (Tables 2 and 3). Planted trees of large, medium, and small size significantly increased the share of evapotranspirational surfaces, comparing to the unit B. The area under trees has also increased, while an important part of the green area $(21.73 \%)$ is transformed into gardens, contributing to higher number of plant species. The vegetative structure of the unit B remained similar to the original idea of public parks, with the limited number of plant species (mostly originally planted trees and shrubs). The available lawn space, due to its poor maintenance, monotonous appearance, and the lack of visual identity, does not attract possible users. According to the conducted interviews of local inhabitants, the place does not instigate any sense of belonging leaving the area without any trigger for the outdoor gatherings, as well as for organized and/or spontaneous activities.

The community gardening in the unit $\mathrm{A}$ has induced many other activities related to open spaces such as sports, relaxation, children's play, etc. Although the visual quality of green space is a subjective category, it should be noted that the main drivers of spontaneous interventions were biophilia and the need for aesthetic and social enjoyment. Given the fact that greenery has been cultivated and maintained for more than 20 years, it is expected that residents' high motivation will continue the process and eventually lead toward continuous investment in local, cost-effective community maintenance.

Table 2. Block 45, morphological unit A.

\begin{tabular}{cc}
\hline Flowers \\
Planters \\
Built-up area (\%) \\
\hline Cultivation and maintenance \\
\hline Pervious surface (\%) \\
\hline Evainly cultivated by self-organized residents; partially maintained by the \\
public company-Belgrade's City Greenery.
\end{tabular}


Table 3. Block 45, morphological unit B.

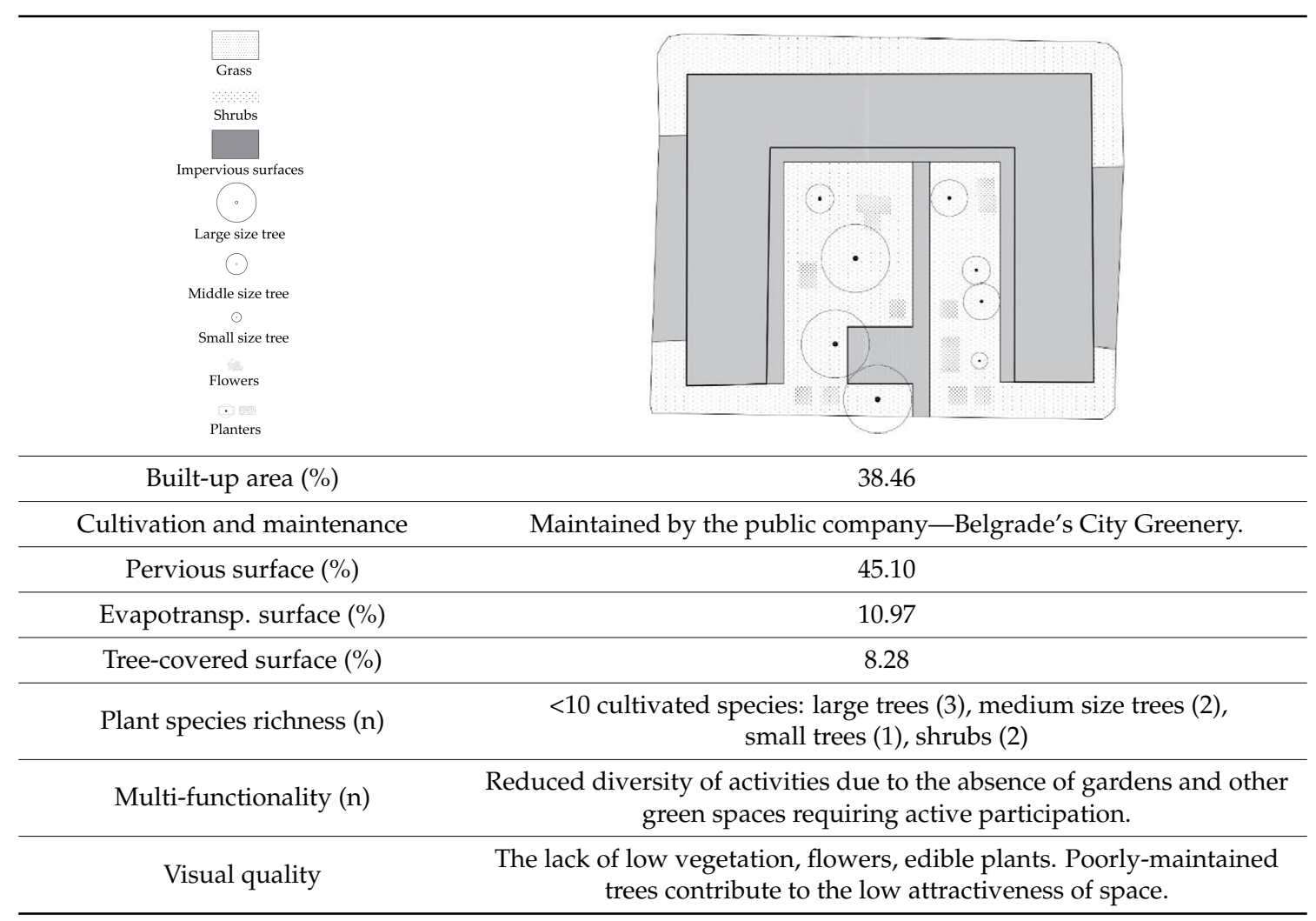

In the case of Savamala, the polygon of the analysis was a perimeter block which includes the building of the 'Mikser' organization (moved out in May 2017), focusing on a small park in front of it. The quality of greenery is compared before and after the campaign of community greening entitled "My piece of Savamala", organized as a workshop in June 2015. Initiated and implemented by NGOs 'Mixer' and 'Urban Guerrilla', it addressed new solutions for this public space in Karadjordjeva Street (Figures 4a,b and 5d,e). The applied participatory design involved local community, experts in the fields of urban planning, architecture, ecology and engineering, as well as the city and municipality authorities, resulting in adopted and implemented actions. On that occasion, the public-private partnership between the city authorities, 'Mixer' and 'Urban Guerrilla' has been established, as a foundation for the further cultivation and maintenance of the park. The most important interventions included the removal of a small gas station, tree planting and introduction of new urban furniture for flowers and green walls. These arrangements have formalized a new mode of cooperation, leading to several anticipatory quantifiable consequences impacting GI.

The Tables 4 and 5 indicate the improvement of the overall quality of the selected unit/green space, according to the criteria of the Green Regulation of Belgrade. The share of pervious surfaces has increased by $4.92 \%$ after the removal of the gas station. Planting three linden trees will increase the evapotranspirational surface by $3.04 \%$ and, in the future, when the trees reach their full diameter of $20 \mathrm{~m}$, the area under treetops will increase from $39.26 \%$ to $41.25 \%$. Urban design interventions (e.g., new urban furniture and pervious pavement) have made space more accessible for a greater number of outdoor activities. Given that community greening represents a recent trend in Savamala, it is not possible to anticipate the motivation and interest of the local community in the long-term. 
Table 4. Savamala, the selected morphological unit before the community action.

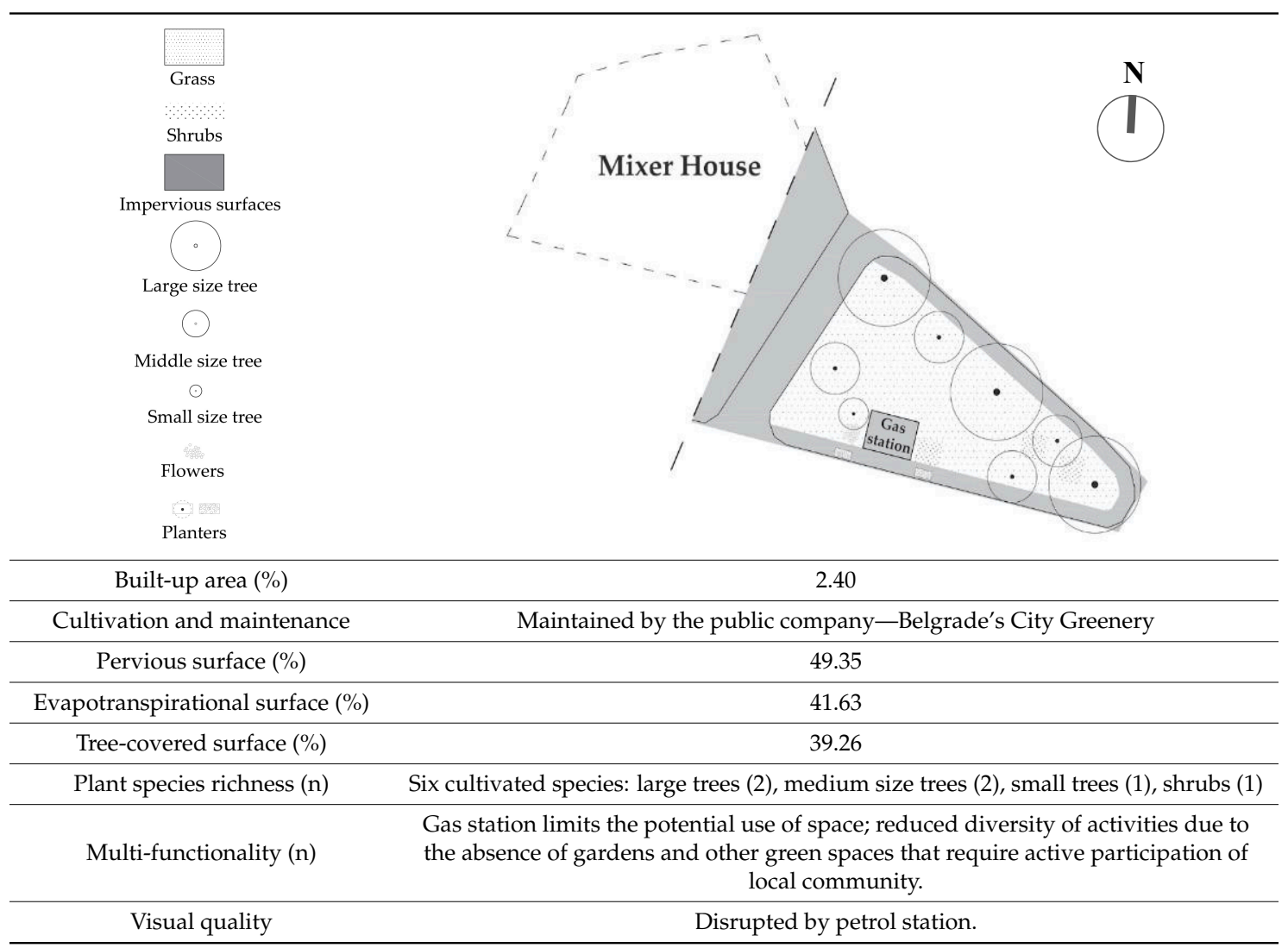

Table 5. Savamala, the selected morphological unit after the community action.

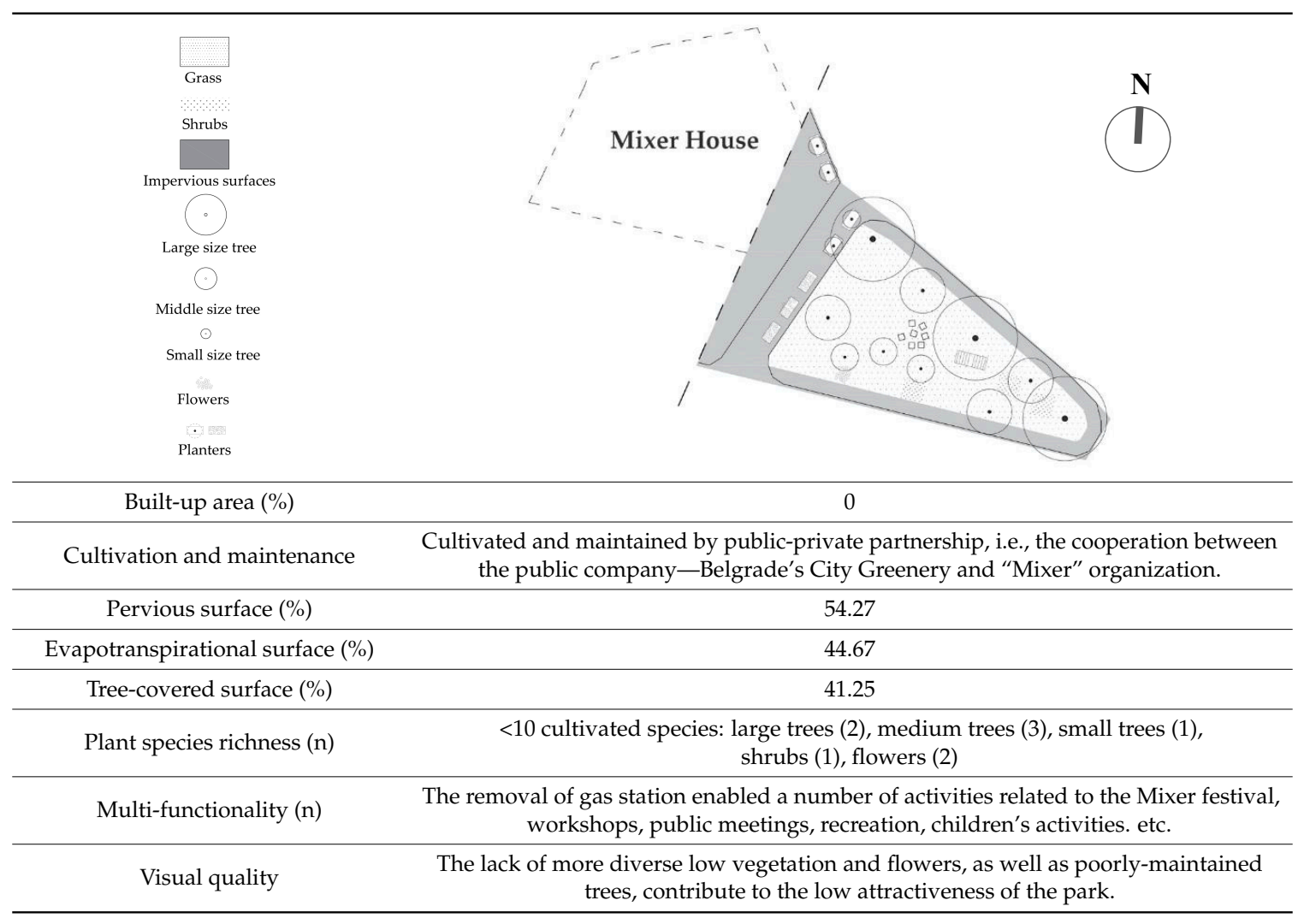




\section{Discussion}

The current socio-economic context in Serbia, resulting in a slow or non-existent implementation of plans, has triggered a number of informal/non-institutional greening initiatives which gradually contribute to the introduction of the contemporary GI concept formulated in the study Green Regulation of Belgrade. The comparative analysis, conducted on two morphologically and functionally different urban matrices in Belgrade, was focused on the level of basic morphological units, identifying the effects of two approaches-spontaneous/community greening and formal/institutional cultivation and maintenance.

In residential Block 45, the residents of unit A undertook individual and collective greening activities, while unit $B$ remained under the exclusive authority of the public greening company. In this case, the indicators showed the overall quality upgrading of green spaces and their environmental performances, i.e., the higher share of permeable and evapotranspiration surfaces, larger areas under the shadow and a higher number of plant species, improved biodiversity and visual attractiveness. As a result, the intensity and number of urban activities has increased. On the local level, the compatibility with the formal GI principles reflects in several elements. For example, the gardens situated between the U-shaped buildings correspond to the GI requirement for the bio-retention function of gardens [17]. The flowerpots added by tenants can take the role of planters for storm water collection. The accessible flat roofs of residential buildings are structurally suitable for adaptation to green roofs. The terraced form of the U-shaped buildings enables the greening of facades. Landscaping conducted by residents could be also extended beyond the existing limits, especially in vacant green spaces around buildings which could be activated.

Savamala, as a mixed-use district, revealed a more complex structure of greening activities, both on the level of organizing and on the level of participants/involved stakeholders. In this case, the main generators of greening activities are local NGOs, local youth organizations, and associations. The selected polygon of the park in front of the Mikser house was activated by the community greening initiated by a public participatory workshop "My piece of Savamala", which led to the more official channels of public-private partnership and cooperation between city's institutions and local organizations. The results of analysis also indicate a moderate success of community greening on the level of vegetation parameters, general accessibility and urban activities. In the terms of compatibility with the formal GI principles and elements, greening of the public spaces in Savamala needs to be directed mainly towards tree planting (both in parks and sidewalks). Furthermore, greening should be extended to inner-block areas (e.g., common gardens with bio-retention) while sidewalks should be upgraded by water permeable features. Buildings with suitable structural properties could be adapted in order to provide green roofs and green facades, which could be jointly used and maintained by residents [17].

The selected cases reveal the importance of community involvement in achieving the higher level of sustainability (economic, social, and environmental) in/of public spaces, especially if they have a potential of becoming an integral part of GI. Although different in typology, contextual elements, and spatial capacity (in both units from Block 45 the public space covers $2984 \mathrm{~m}^{2}$ comparing to current $1232 \mathrm{~m}^{2}$ in the Savamala case), they also confirm that environmental quality represents both an aim and a generator of change. It raises general attractiveness and number of users, defines urban identity and sense of belonging simultaneously stimulating environmental consciousness and well-being of all stakeholders. This sensitive and complex relationship between users and public space could be also seen in two different approaches applied in Block 45, in which the urbo-morphological unit A developed an informal process of greening, unlike option B. Although the motives of this discrepancy were not a subject of this article and they need a comprehensive analysis, the conducted interviews reveal the importance of the sense of belonging to a neighbourhood (e.g., the status of home-ownership vs. renting/temporary stay) might have on developing community initiatives.

Apart from the detected improvement of green areas, the selected polygons also showed the shortcomings of existing legislation related to GI, both on the city and the municipal level. Although 
APCCA recognizes local community as one of the stakeholders and mentions some greening modes (urban gardens, eco-parks), the role of community greening within GI framework is vaguely defined, without a notion of possible models of organization, management and financing. Consequently, all detected initiatives remain insufficiently aligned with the regulations. The municipality of Novi Beograd still does not use Local ecological action plan (as the only relevant plan dealing with GI on the local level) and the community greening in Blok 45 remains legally unrecognized and unsupported. In Savamala, the ad hoc solution of public-private partnerships was created, aligning with city regulations. However, this approach is not consistent with LEAP, which fails to fully describe all of the aspects of community involvement in formal action plans of GI.

The neighbouring countries could provide some examples of a successful interaction between community greening and official regulations, strategies and plans for the development of GI, both on city and municipal levels. The city of Budapest, which also had difficulties in including the local initiatives in GI strategies and plans, tackles the problem by engaging a well-organized civil sector, like in the case of the organization Contemporary Architecture Centre (KÉK), which has been a part of the dissemination process related to urban gardening in Hungary since 2010. KÉK represents a mediator between local initiatives and local governments in order to find the optimal models of cooperation. As a professional partner, they have contributed in setting up many community and school gardens, while operating four of them in Budapest [41]. In addition, Vienna, as a city with a long tradition in community gardening, has developed its own system which involves local initiatives in formal action plans. As a result, the local government encourages locals (individual gardeners, neighbourhood co-operatives, "guerrilla gardening", etc.) to contribute to greening activities in public and private urban spaces. The community administration (Gebietsbetreuung) receives proposals for individual gardens and public urban spaces and considers the possibility of their implementation. The City of Vienna approved financial support for one community garden in each district, while 'neighbourhood plots' represents a municipally-funded form of urban gardening [42].

A successful model, also applicable in Serbian case, has been conducted in Berlin. The link between individual greening and public GI infrastructure has been established through the process of the BAF implementation (BAF-Biotope Area Factor, used to estimate ecological effectiveness). If an individual parcel is not able to achieve the expected referent (BAF) standards, the greening of public spaces in immediate surroundings should compensate the imbalance [15]. In this way, plot-owners are engaged in greening activities in the public space, simultaneously improving GI at the local level.

\section{Conclusions}

Based on the case studies, we conclude that, for the time being, the regulations and plans offer no comprehensive and harmonized solutions that recognize the contemporary approaches to green infrastructure, the role of participatory design with stakeholders, and the importance of community greening at the local level. This primarily outlines the need to establish a problem-specific approach in planning GI at the local level, which takes into account the specifics of greening activities defined and modified by different socio-economic and ecological circumstances, as well as morphological limitations. Therefore, the results may be applicable primarily in terms of further local-sensitive initiatives. It should be noted that the analysis was restricted only to certain elements concerning legislation, ecosystem performance and functionality, and did not consider the economic aspect which is also important for the development and implementation of GI.

Considering the selected polygons, the results of the analysis could be very useful for the Belgrade's areas with similar characteristics, and may apply in future studies, local plans, and urban design of GI. The analysis and assessment conducted in both cases reveal that the activities of community greening have significantly improved the condition of GI, previously maintained only by the public company (Belgrade's City Greenery). The overall quality and quantity of greenery has been increased, as well as its variety and the intensity of use. Two different morphological units (Block 45 
and Savamala), placed in different urban settings, have generated diverse approaches to community greening, with a specific structure and organization of actors, but their activities in both cases have contributed to the overall quality of GI.

Furthermore, the identified activities of community greening have a potential which could be extended and used on the local level, as a channel for dissemination of environmentally friendly ideas and lifestyles, as well as for the improvement of environmental consciousness. The detected trend of urban gardening should be also upgraded in order to exceed its current scale, stimulate the practice of self-organization and intensify self-initiated refining of green areas in the immediate surroundings. Additionally, these cases could be used as examples for the countries in the Balkan region, with similar planning and legislative systems, social-economic contexts, and ex-socialist legacies reflected in the urban environment.

Acknowledgments: The article is realized as part of the project "Studying climate change and its influence on the environment: impacts, adaptation and mitigation" (43007) financed by the Ministry of Education and Science of the Republic of Serbia within the framework of integrated and interdisciplinary research for the period 2011-2017.

Author Contributions: All three authors wrote the article, read, and approved the manuscript. Ivan Simić performed the literature review, collected and analysed the data, prepared the graphic material, and defined the methodology. Aleksandra Stupar, as the academic advisor, was in charge of the interdisciplinary approach, methodology, structure, and the article editing. Vladan Dokić, as the academic advisor related to the issues of urban morphology, contributed to interpreting the data and the article editing.

Conflicts of Interest: The authors declare no conflict of interest.

\section{References}

1. Pelkonen, V.; Kohl, J. The role of local ecological knowledge in sustainable urban planning: Perspectives from Finland. Sustain. Sci. Pract. Policy 2005, 1, 3-14.

2. Pelkonen, V.; Niemelä, J. Linking ecological and social systems in cities: Urban planning in Finland as a case. Biodivers. Conserv. 2005, 14, 1947-1967. [CrossRef]

3. Wilson, E.; Piper, J. Spatial Planning and Climate Change; Routledge: London, UK, 2010.

4. Pickett, S.T.A.; Cadenasso, M.L.; Grove, J.M. Resilient cities: Meaning, models, and metaphor for integrating the ecological, socioeconomic, and planning realms. Land Urban Plan. 2004, 69, 69-384. [CrossRef]

5. Ahern, J. Green infrastructure for cities: The spatial dimension. In Cities of the Future towards Integrated Sustainable Water and Landscape Management; Novotny, V., Brown, P., Eds.; IWA Publishing: London, UK, 2007; pp. 267-283.

6. Benedict, M.A.; McMahon, E.T. Green Infrastructure: Smart Conservation for the 21st Century; The Conservation Fund and Sprawl Watch Clearinghouse: Arlington, VA, USA, 2002.

7. Raven, J. Cooling the Public Realm: Climate-Resilient Urban Design. In Resilient Cities: Cities and Adaptation to Climate Change; Zimmermann, K., Ed.; Springer: Heidelberg, Germany, 2011; pp. 451-463.

8. Tidball, K.G.; Krasny, M.E. From risk to resilience: What role for community greening and civic ecology in cities? In Social learning towards a More Sustainable World; Wals, A.E.J., Ed.; Wageningen Academic Publishers: Wageningen, The Netherlands, 2009; pp. 149-165.

9. Gill, S.E.; Handley, J.F.; Ennos, A.R.; Pauliet, S. Adapting Cities for Climate Change: The Role of Green Infrastructure. Built Environ. 2007, 33, 115-133. [CrossRef]

10. Ndubisi, F. Ecological Planning: A Historical and Comparative Synthesis; Johns Hopkins University Press: Baltimore, MD, USA, 2002.

11. Irvine, K.N.; Fuller, R.A.; Devine-Wright, P.; Tratalos, J.; Payne, S.R.; Warren, P.H.; Lomas, K.J.; Gaston, K.J. Ecological and Psychological Value of Urban Green Space. In Dimensions of Sustainable City, Future City 2; Jenks, M., Jones, C., Eds.; Springer: London, UK, 2010; pp. 215-237.

12. Lafortezza, R.; Davies, C.; Sanesi, G.; Konijnendijk, C. Green Infrastructure as a tool to support spatial planning in European urban regions. iForest 2013, 6, 102-108. Available online: http:/ /www.sisef.it/iforest/ contens/?id $\backslash \mathrm{T} 1 \backslash$ textquoterightifor0723--006 (accessed on 5 March 2013). [CrossRef]

13. Lovell, S.T.; Taylor, J.R. Supplying urban ecosystem services through multifunctional green infrastructure in the United States. Land Ecol. 2013, 28, 1447-1463. [CrossRef] 
14. Zaręba, A. Multifunctional and Multiscale Aspects of Green Infrastructure in Contemporary Research. Prob. Sust. Dev. 2014, 9, 149-156.

15. Senate Department for the Environment, Transport and Climate Protection. Biotope Area Factor (BAF). 1990. Available online: http://www.stadtentwicklung.berlin.de/umwelt/landschaftsplanung/bff/index_ en.shtml (accessed on 10 September 2016).

16. Kruuse, A. The Green Space Factor and the Green Points System. 2011. Available online: http:/ / www.malmö. se/download/18.d8bc6b31373089f7d980008924/1491301018437/greenspacefactor_greenpoints_grabs.pdf (accessed on 10 September 2016.).

17. Hirst, J. Seattle Green Factor (SGF). 2008. Available online: http://www.asla.org/2010awards/519.html (accessed on 2 August 2016).

18. Krasny, M.E.; Tidball, K.G. Civic Ecology: Adaptation and Transformation from the Ground Up; MIT Press: Cambridge, MA, USA, 2015.

19. Colding, J.; Barthel, S. The potential of 'Urban Green Commons' in the resilience building of cities. Ecol. Econ. 2013, 86, 156-166. [CrossRef]

20. Pietrzyk-Kaszynska, A.; Czepkiewicz, M.; Kronenberg, J. Eliciting non-monetary values of formal and informal urban green spaces using public participation GIS. Land. Urban Plan. 2017, 160, 85-95. [CrossRef]

21. Kinzig, A.; Warren, P.; Martin, C.; Hope, D.; Katti, M. The effects of human socioeconomic status and cultural characteristics on urban patterns of biodiversity. Ecol. Soc. 2005, 10. Available online: http: / / www.ecologyandsociety.org/vol10/iss1/art23/ (accessed on 17 June 2016). [CrossRef]

22. Master Plan of Belgrade to 2021. 2016. Available online: http://www.urbel.com/default.aspx?ID=uzb_ GeneralniPlanovi\&LN=SRL (accessed on 17 December 2015).

23. City of Belgrade Development Strategy (CBDS) 2011-2016 (Strategija razvoja grada Beograda 2011-2016). 2010. Available online: http:/ / www.beograd.rs/download.php/documents/SRGBpredlog.pdf (accessed on 28 May 2016).

24. Cvejić, J. Local ecological action plan (LEAP) of Savski Venac Municipality (Lokalni Ekološki Akcioni Plan Gradske Opštine Savski Venac). 2010. Available online: http:/ /www.savskivenac.rs/ekoppt/2010-4.pps (accessed on 18 May 2016).

25. Cvejić, J.; Bajc, Lj. Zelena Regulativa Beograda (Green regulation of Belgrade). 2003. Available online: http:/ / www.urbel.com/documents/zelena_regulativa_beograd.pdf (accessed on 18 May 2016).

26. MapSoft. Geographical Information System (GIS) of Biotopes of Belgrade. 2008. Available online: https: / / gisbiotopa.beograd.gov.rs/Map (accessed on 18 May 2016).

27. Forman, R. Land Mosaics: The Ecology of Landscapes and Regions; Cambridge University Press: London, UK, 1995.

28. Cvejić, J.; Teofilović, A. Concept of Green Spaces System-Belgrade Case Study. In Proceedings of the Fabos Conference on Landscape and Greenway Planning, Budapest, Hungary, 8-11 July 2010; pp. 171-178.

29. Teofilović, A.; Cvejić, J.; Tutundžić, A. Program za Urbanistički Plan Sistema Zelenih Površina Beograda, Projekat "Zelena regulativa Beograda" (IV faza); Urbanistički Zavod Beograda: Belgrade, Serbia, 2009.

30. Đokić, N.; Grujić, M. Action Plan for Climate Change Adaptation for City of Belgrade. 2015. Available online: http:/ / klimatskepromenebeograd.rs/wp-content/uploads/2015/11/Climate-Change-AdaptationAction-Plan.pdf (accessed on 28 April 2016).

31. Forman, R.T.T.; Godron, M. Landscape ecology; John Wiley \& Sons: New York, NY, USA, 1986.

32. Cvejić, J.; Bobić, A.; Teofilović, A.; Tutundžić, A.; Radulović, S. Adaptacija Kompaktnog grada na Klimatske Promene: Primena Ekološkog Modela u Beogradu. In Uticaj Klimatskih Promena na Planiranje i Projektovanje; Đokić, V., Lazović, Z., Eds.; Faculty of Architecture: Belgrade, Serbia, 2012; pp. 83-109.

33. Master Plan of Belgrade 1950; Urban Planning Institute of Belgrade: Belgrade, Serbia, 1950.

34. Draft of the Detailed Regulation Plan for Blocks 45 and 70; Urban Planning Institute of Belgrade: Belgrade, Serbia, 2003.

35. Graovac, A.; Teofilović, V.; Lalić, I. Dve strane Planerske Medalje: Planovi Detaljne Regulacije za Blokove 45 i 70 u Novom Beogradu. 2015. Available online: http://www.ingkomora.org.rs/materijalpo/download/ 2015/20150320_dve_strane_planerske_medalje.pdf (accessed on 22 July 2016).

36. Stanojković, M. Oasis between Blocks on New Belgrade. 2016. Available online: http:/ /www.novosti.rs / vesti/lifestyle.677.html:633910-Oaza-medju-blokovima-na-Novom-Beogradu (accessed on 22 July 2016). 
37. Mapping and Evaluating Biotopes of Belgrade (Kartiranje i Vrednovanje Biotopa Beograda). 2007. Available online: http:/ / www.urbel.com/documents/info20-tema.pdf (accessed on 28 May 2016).

38. Blue-green dream. 2014. Available online: http://www.slideshare.net/NALED/the-story-of-mikser (accessed on 28 June 2016).

39. Zdravamala (Healthy Savamala). 2015. Available online: http://urbanincubator.org/portfolio_page/ zdravamala/ (accessed on 18 May 2016).

40. My piece of Savamala-City Guerilla (Moje parče Savamale—Gradska gerila). 2015. Available online: http:/ / festival.mikser.rs/en/project/my-piece-of-savamala/ (accessed on 28 May 2016).

41. Kertesz, M. Contemporary Architecture Center organization (KÉK)-Community Gardens. 2016. Available online: http:/ / kek.org.hu/en/projekt/kertek/ (accessed on 22 July 2016).

42. Zoidl, F. Vienna Review-Urban Gardening. 2013. Available online: http://www.viennareview.net/ services / keys-to-the-city/urban-gardening (accessed on 22 July 2016.).

(C) 2017 by the authors. Licensee MDPI, Basel, Switzerland. This article is an open access article distributed under the terms and conditions of the Creative Commons Attribution (CC BY) license (http:// creativecommons.org/licenses/by/4.0/). 